\title{
The American-European Consensus Conference definition of the acute respiratory distress syndrome is dead, long live positive end-expiratory pressure!
}

\author{
J. Villar ${ }^{a, b, *}$, R.M. Kacmarek ${ }^{c, d}$ \\ a CIBER de Enfermedades Respiratorias, Instituto de Salud Carlos III, Madrid, Spain \\ ${ }^{\mathrm{b}}$ Multidisciplinary Organ Dysfunction Evaluation Research Network, Research Unit, Hospital Universitario Dr. Negrin, Las Palmas \\ de Gran Canaria, Spain \\ c Department of Respiratory Care, Massachusetts General Hospital, Boston, MA, USA \\ 'Department of Anesthesia, Harvard University, Boston, MA, USA
}

\author{
KEYWORDS \\ Acute respiratory \\ distress syndrome; \\ Positive \\ end-expiratory \\ pressure; \\ Standard ventilatory \\ settings; \\ American-European \\ Consensus \\ Conference; \\ $\mathrm{PaO}_{2} / \mathrm{FiO}_{2}$ ratio
}

\section{PALABRAS CLAVE \\ Síndrome de dificultad respiratoria aguda; \\ Positiva al final de la espiración la presión; Estándar de parámetros ventilatorios;}

\begin{abstract}
In 1994, an American-European Consensus Conference (AECC) formalized the criteria for the diagnosis of the acute respiratory distress syndrome (ARDS). Although that definition is simple to apply in the clinical setting, it has been challenged over the years in several studies since the assessment of the oxygenation defect does not require standardized ventilatory support. We were the first to propose new guidelines, based on a specific, standard method of evaluating oxygenation status, a proposal that was later advocated by others. To address the limitations of the AECC definition, a modified ARDS definition has been proposed by a task force panel of experts, referred to as the Berlin Defintion, using a terminology similar to that we previously proposed. However, that proposal has several methodological flaws. Since all ARDS patients start off with terrible oxygenation, the Berlin Definition offers no room for stratifying and identifyng true ARDS patients since there is no further re-evaluation of the hypoxemia under standard ventilator setting in a specific time period. In this Point of View, we review the history of the definition of ARDS and discussed the methodological concerns regarding adopting this new, revised ARDS definition.
\end{abstract}

(c) 2012 Elsevier España, S.L. and SEMICYUC. All rights reserved.
La definición del síndrome de distrés respiratorio agudo según la Conferencia de Consenso Americana-Europea está muerta, ¡larga vida a la presión positiva espiratoria final!

Resumen En 1994, una Conferencia de Consenso Americana-Europea (CCAE) formalizó los criterios para el diagnóstico del Síndrome de Distrés Respiratorio Agudo (SDRA). Aunque esa definición es sencilla de aplicar en la clínica, ha sido criticada en varios estudios ya que la medida del defecto de oxigenación no requiere de la estandarización del soporte ventilatorio. Nosotros fuimos los primeros en proponer nuevas guías basadas en un método estándar específico para evaluar el estado de la oxigenación, una propuesta que más tarde fue apoyada por

\footnotetext{
* Corresponding author.

E-mail address: jesus.villar54@gmail.com (J. Villar).
}

0210-5691/\$ - see front matter @ 2012 Elsevier España, S.L. and SEMICYUC. All rights reserved. http://dx.doi.org/10.1016/j.medin.2012.08.010 
American-European

Consensus

Conference;

Relación $\mathrm{PaO}_{2} / \mathrm{FiO}_{2}$ otros autores. Para solucionar las limitaciones de la definición de la CCAE del SDRA, una modificación de esta definición ha sido propuesta por un panel de expertos, denominada Definición de Berlín, utilizando una terminología similar a la que nosotros habíamos propuesto previamente. Sin embargo, esta nueva propuesta tiene varios fallos metodológicos. Debido a que todos los pacientes con SDRA presentan inicialmente una oxigenación terrible, la Definición de Berlín no facilita la estratificación e identificación de verdaderos pacientes con SDRA porque no da la posibilidad de volver a evaluar el grado de hipoxemia bajo un patrón estándar de ventilación en un tiempo determinado. En este Punto de Vista revisaremos la historia de la definición del SDRA y analizaremos los problemas metodológicos relacionados con la adopción de esta nueva revisión de la definición del SDRA.

(c) 2012 Elsevier España, S.L. y SEMICYUC. Todos los derechos reservados.
"The King is dead. Long live the King!" is a traditional proclamation made following the accession of a new monarch in various countries. The original phrase was translated from the French Le Roi est mort, vive le Roi!, which was first declared upon the accession to the French throne of Charles VII after the death of his father Charles VI in 1422. ${ }^{1}$ We were inspired by this proclamation when patients diagnosed with the acute respiratory distress syndrome (ARDS) according to the American-European Consensus Conference (AECC) criteria $^{2}$ were evaluated under standard ventilatory setting that included a specific level of positive end-expiratory pressure (PEEP) and inspired oxygen concentration $\left(\mathrm{FiO}_{2}\right){ }^{3-5}$ We observed that: (i) about half of the ARDS patients were improperly classified as having ARDS, and (ii) ARDS patients could be stratified by lung severity according to their response to a PEEP- $\mathrm{FiO}_{2}$ trial within the first $24 \mathrm{~h}$ of meeting the AECC ARDS criteria. ${ }^{3-5}$ Based on our reports, a proposal to address the limitations of the AECC definition and to update the AECC ARDS definition has been published recently ${ }^{6}$ by a task force panel of experts using terminology similar to that we previously proposed. . $^{5,7}$, However, that proposal has several methodological flaws. But first, let us review briefly the short history of the definition of ARDS.

\section{Introduction and historical remarks}

In August 1967, Ashbaugh et al. ${ }^{9}$ described for the first time a syndrome that they termed the ARDS. They studied a cohort of 272 patients who were receiving respiratory support, and from this cohort they identified 12 patients with a syndrome that was similar to the Infant Respiratory Distress Syndrome. The respiratory distress was defined as sudden, catastrophic, and often associated with a multiorgan system insult which led to tachypnea, hypoxemia, decreased respiratory system compliance, and bilateral pulmonary infiltrates on chest X-ray due to non-cardiogenic pulmonary edema. The mortality rate was $58 \%$ and on pathological examination the lungs of the non-survivors were heavy, atelectatic, with interstitial and alveolar edema, and hyaline membranes. Since that time, the hallmark of this syndrome has included: (i) a risk factor for the development of ARDS, (ii) severe hypoxemia with a relatively high $\mathrm{FiO}_{2}$, (iii) bilateral pulmonary infiltrates, and (iv) no clinical evidence of cardiogenic pulmonary edema, although acute lung injury (ALI) resulting in ARDS can also occur in the setting of left ventricular failure.

ARDS is caused by an inflammatory insult to the alveolarcapillary membrane that results in increased permeability and subsequent interstitial and alveolar edema. ${ }^{10}$ Unlike other forms of acute respiratory failure and like all forms of tissue inflammation, ALI during ARDS represents a complex process in which multiple cellular signaling pathways propagate or attenuate lung damage. Since it is difficult to measure changes in capillary and alveolar permeability at the bedside, diagnosis of ARDS is based on a combination of clinical, oxygenation, hemodynamic and radiographic criteria. These criteria allow the inclusion of a heterogeneous group of critically ill patients since various types of injury can lead to a similar pulmonary response. The original description of ARDS was incapable of identifying a uniform group of patients. Several patients from the original cohort would not be classified as ARDS today, since fluid overload was an important etiological factor. Thus, a precise definition is important for accurate identification and quantification of various aspects of the underlying pathophysiology and to select the best therapeutic approach in selected subgroups of patients.

Given that severe hypoxemia is the hallmark of ARDS, hypoxemia is crucial to the assessment of the severity of ARDS, for predicting the evolution in any given patient, and for assessing the response to treatment. In order to better characterize the severity of lung damage, the $\mathrm{AECC}^{9}$ defined ALI and ARDS as follows: (i) acute and sudden onset of severe respiratory distress; (ii) bilateral infiltrates on frontal chest radiograph; (iii) the absence of left atrial hypertension (a pulmonary capillary wedge pressure $<18 \mathrm{mmHg}$ or no clinical signs of left ventricular failure); and (iv) severe hypoxemia (assessed by the $\mathrm{PaO}_{2} / \mathrm{FiO}_{2}$ ratio). According to these guidelines, $\mathrm{ALI}$ exists when the $\mathrm{PaO}_{2} / \mathrm{FiO}_{2}$ ratio is $\leq 300$ and $>200 \mathrm{mmHg}$ regardless of the PEEP and $\mathrm{FiO}_{2}$, and ARDS when the $\mathrm{PaO}_{2} / \mathrm{FiO}_{2}$ ratio is $\leq 200 \mathrm{mmHg}$ again regardless of PEEP and $\mathrm{FiO}_{2}$. Although this definition formalized the criteria for the diagnosis of ARDS and is simple to apply in the clinical setting, it has been challenged over the years in several studies. ${ }^{3,8,11}$ All patients start off with terrible oxygenation and there is little room for stratifying the patients if there is no further re-evaluation of the hypoxemia. Also, the physiological thresholds of the AECC definition do not 
require standardized ventilatory support. The use of PEEP can improve oxygenation indices sufficiently to change the physiology of the lung converting patients meeting the definition of ARDS to patients not meeting the ARDS definition. Therefore, a patient could fit the ARDS criteria when the $\mathrm{PaO}_{2}$ is measured with zero PEEP but not when measured at a PEEP of 5 or $10 \mathrm{cmH}_{2} \mathrm{O}$, or when measured on $\mathrm{FiO}_{2}=0.35$ but not when measured on $\mathrm{FiO}_{2}=0.5$. $^{3,5,11}$ These findings illustrate the major problems experienced when trying to compare the results of various clinical trials evaluating ventilatory strategies, since patients with very different levels of lung dysfunction and disease may have been enrolled.

\section{An early $\mathrm{PEEP} / \mathrm{FiO}_{2}$ trial identifies different degrees of ARDS severity}

In 1999, Villar et al. ${ }^{3}$ proposed the need for different guidelines, based on a specific, standard method of evaluating oxygenation status, a proposal that was later advocated by others. ${ }^{11}$ In order to determine the impact of various PEEP and $\mathrm{FiO}_{2}$ levels on the stratification of patients meeting the AECC ARDS definition, Villar et al. ${ }^{5}$ evaluated the impact of standard ventilation settings applied on the day patients met the AECC ARDS criteria and $24 \mathrm{~h}$ later. They studied 170 patients and found that only $58 \%$ of them fulfilled ARDS criteria when evaluated on PEEP $\geq 10 \mathrm{cmH}_{2} \mathrm{O}$ and $\mathrm{FiO}_{2} \geq 0.5$ at $24 \mathrm{~h}$ after meeting the AECC ARDS definition. The ICU mortality of those patients was $46 \%$. By contrast, $32 \%$ of patients were classified as having ALI (their mortality was 20\%), and $10 \%$ of patients had a $\mathrm{PaO}_{2} / \mathrm{FIO}_{2}>300 \mathrm{mmHg}$ and were simply categorized as having acute respiratory failure (their ICU mortality was 6\%). This study demonstrated the large variability in the severity of lung damage in patients who initially meet the AECC definition of ARDS and the strong correlation between oxygenation impairment at $24 \mathrm{~h}$ after ARDS onset and ICU outcome. The major implication of these findings is that the use of the AECC ARDS definition to enroll patients into clinical trials may result in the inclusion of patients with highly variable severity of lung injury and mortalities. If the subjects in a trial have a very low risk of the condition that the intervention is hypothesized to prevent, the trial regardless of sample size - will not verify the value of the intervention. ${ }^{12}$ For example, in the ARDSnet trial, ${ }^{13} 17 \%$ of enrolled patients did not have ARDS but were included in the overall analysis. Consequently, it can be argued that the ARDSnet trial failed to focus on the highest risk patients.

A PEEP and $\mathrm{FiO}_{2}$ trial $24 \mathrm{~h}$ after ARDS onset is an easy and simple strategy to find or identify subpopulations of ARDS patients at highest risk. ${ }^{4}$ It is not difficult to explain why patients initially meeting AECC ARDS criteria would fail to meet the same criteria on standard ventilator setting. It is well established that changes in PEEP and $\mathrm{FiO}_{2}$ alter the $\mathrm{PaO}_{2} / \mathrm{FiO}_{2}$ values in lung-injured patients. ${ }^{14,15}$ PEEP can improve oxygenation sufficiently to change the physiology of the lung. ${ }^{15}$ If PEEP is inadequate, the lung collapses during expiration allowing alveolar derecruitment and causing ventilator-induced lung injury. The lack of a standard PEEP and $\mathrm{FiO}_{2}$ setting in the AECC definitions may explain the negative results of published trials of various therapeutic interventions on patients with ALI/ARDS. ${ }^{16-18} \mathrm{Few}$ of these negative trials used the AECC definition for ARDS, and none required standard ventilator settings to qualify patients for enrollment. Because many patients without sustained ARDS may have been enrolled, it is conceivable that a disproportionate number of patients meeting ALI or ARF criteria ended up in the control arm, negating the beneficial effect of the treatment because of the lower mortality of these patients. This is contrary to published data from Villar et al. ${ }^{4}$ From a cohort of 311 patients meeting AECC criteria, only 103 patients (33.1\%) qualified as having ARDS on a standard PEEP-FiO 2 setting (PEEP $\geq 5 \mathrm{cmH}_{2} \mathrm{O}$ with $\left.\mathrm{FiO}_{2} \geq 0.5\right)$ at $24 \mathrm{~h}$ after screening. This resulted in a homogeneous group of patients in whom the benefit or lack of benefit of a therapy could be appropriately evaluated. Most of the 208 patients (66.9\%) who did not qualify as ARDS at $24 \mathrm{~h}$ had a transient fall of $\mathrm{PaO}_{2} / \mathrm{FiO}_{2}$ or the $\mathrm{PaO}_{2}$ was measured while receiving PEEP $<5 \mathrm{cmH}_{2} \mathrm{O}$ and/or $\mathrm{FiO}_{2}<0.5$. Several other patients had a marked improvement of their pulmonary dysfunction within the first $24 \mathrm{~h}$.

Initial ventilatory settings in the management of patients with ALI and ARDS may affect the prevalence of ARDS. In a recent epidemiological study, Villar et al. ${ }^{7}$ found that the current incidence of ARDS in Spain using protective mechanical ventilation (low tidal volume plus moderate to high PEEP levels) before and after the diagnosis of ARDS was very low, and dramatically lower than the incidence values reported in other studies where patients were ventilated with higher tidal volumes and lower levels of PEEP. ${ }^{19-21}$ In the Villar et al. study, ${ }^{7}$ most patients $(87 \%)$ were treated within the first $24 \mathrm{~h}$ with PEEP $\geq 10 \mathrm{cmH}_{2} \mathrm{O}$ and $14 \%$ received $15-24 \mathrm{cmH}_{2} \mathrm{O}$ PEEP. Under these circumstances, when patients were categorized by their initial $\mathrm{PaO}_{2} / \mathrm{FiO}_{2}$ range at the time of ARDS identification, almost half of patients (46\%) had severe ARDS $\left(\mathrm{PaO}_{2} / \mathrm{FiO}_{2} \leq 100\right)$ and their mortality was 1.5 times higher than the mortality of patients with a $\mathrm{PaO}_{2} / \mathrm{FiO}_{2}$ between $>100$ and $200 \mathrm{mmHg}(52.1 \%$ vs. $34.8 \%$, $p<0.01)$. López-Fernández et al. ${ }^{8}$ recently performed the largest epidemiological study on pediatric ARDS in the Western world and the only one using the AECC criteria in which most children received protective mechanical ventilation. In addition to reporting that the incidence of pediatric ARDS is lower than those reported in adults, the major contribution of their study was that the comparison of $\mathrm{PaO}_{2} / \mathrm{FiO}_{2}$ ratios at baseline $(\leq 100 \mathrm{mmHg}$ vs. $>100 \mathrm{mmHg})$ and the persistence of $\mathrm{PaO}_{2} / \mathrm{FiO}_{2} \leq 200$ in response to $P E E P \geq 10 \mathrm{cmH}_{2} \mathrm{O}$ on $\mathrm{FiO}_{2} \geq 0.5$, was a predictor of outcome since it identified subgroups of patients with different lung severity and mortality. Although the overall mortality of the cohort was low (26\%), the stratification based on the range of $\mathrm{PaO}_{2} / \mathrm{FiO}_{2}$ ratio measured under standard ventilator settings at $24 \mathrm{~h}$ after ARDS onset, was able to identify four subgroups of patients with markedly different mortalities: only $44.5 \%$ of patients had severe ARDS $\left(\mathrm{PaO}_{2} / \mathrm{FiO}_{2} \leq 100\right), 36.3 \%$ had moderate ARDS $\left(\mathrm{PaO}_{2} / \mathrm{FiO}_{2}\right.$ $101-200), 11.6 \%$ had $\mathrm{ALI}\left(\mathrm{PaO}_{2} / \mathrm{FiO}_{2} 201-300\right)$; and $7.5 \%$ had ARF $\left(\mathrm{PaO}_{2} / \mathrm{FiO}_{2}>300\right)$, while the mortality rates were $38.5 \%, 20.7 \%, 11.8 \%$, and $0 \%$, respectively $(p<0.001)$.

\section{The "Berlin Definition"}

A proposal for an update of the AECC ARDS definition has been published recently ${ }^{6}$ by a task force panel of 
experts using a similar terminology as we had previously reported. Using teleconferencing, in-person discussions and retrospective data, they proposed an ARDS classification with three severity categories (mild, moderate, and severe) for empirical evaluation. The term "mild" ARDS was used for defining those patients who are considered as $\mathrm{ALI}$ in the $\mathrm{AECC}$ definition $\left(300 \geq \mathrm{PaO}_{2} / \mathrm{FiO}_{2}>200 \mathrm{mmHg}\right)$. The term "moderate" was used for patients with a $\mathrm{PaO}_{2} / \mathrm{FiO}_{2}>100 \mathrm{mmHg}$ but $<200$, and the term "severe" for those with a $\mathrm{PaO}_{2} / \mathrm{FiO}_{2} \leq 100 \mathrm{mmHg}$. The panel used 7 datasets: 4 from multicenter studies (enrolling 4188 patients with a $\mathrm{PaO}_{2} / \mathrm{FiO}_{2} \leq 300 \mathrm{mmHg}$ ), and 3 from small, singlecenter studies (enrolling 269 patients). By considering only those patients from the multicenter studies who were managed with PEEP $\geq 5 \mathrm{cmH}_{2} \mathrm{O}$ at the time of study enrollment, the panel found that hospital mortality increased with every stage of severity (mild $27 \%$, moderate $32 \%$, severe $45 \%$ ). In the database from the 3 small, single-center studies comprising 269 patients, the hospital mortality increased as well with every stage of ARDS (mild 20\%, moderate $41 \%$, severe $52 \%)$. Although the authors stated that the purpose of their empirical definition was not to develop a prognostic tool, this exercise should be cautiously generalized for the following methodological reasons.

First, none of the patients included in the empirical analysis were prospectively enrolled for the purpose of revising the ARDS definition and/or evaluating risk stratification. Second, the categorization of patients was done based on the $\mathrm{PaO}_{2} / \mathrm{FiO}_{2}$ value at the time of inclusion into their respective observational study or randomized clinical trial. There is no information on whether those baseline values of $\mathrm{PaO}_{2} / \mathrm{FiO}_{2}$ were calculated at the time of ARDS onset or during any time of their disease process, or whether the $\mathrm{PaO}_{2}$ was measured under a known $\mathrm{FiO}_{2}$ and PEEP level. In our studies, ${ }^{3,8} \mathrm{PaO}_{2} / \mathrm{FiO}_{2}$ was always calculated from the $\mathrm{PaO}_{2}$ values measured 30 min after each standard ventilator setting under a specified $\mathrm{FiO}_{2}$ and PEEP level. Third, 24\% of patients included had $\mathrm{a}^{\mathrm{PaO}} \mathrm{O}_{2} / \mathrm{FiO}_{2}>200$ at the time of enrollment (classified as non-ARDS by the AECC definition). We did not include those patients in our studies because in many centers they are usually not treated with endotracheal intubation and invasive MV. However, we have reported that in about $40 \%$ of ARDS patients, $\mathrm{PaO}_{2} / \mathrm{FiO}_{2}$ increased above $200 \mathrm{mmHg}$ when they were evaluated on PEEP $\geq 10$ and $\mathrm{FiO}_{2} \geq 0.5$ at $24 \mathrm{~h}$ after being diagnosed as having ARDS according to the AECC definition. ${ }^{4,5}$ Fourth, the empirical definition did not consider the level of $\mathrm{FiO}_{2}$ for $\mathrm{PaO}_{2} / \mathrm{FiO}_{2}$ categorization despite the fact that changes in the applied $\mathrm{FiO}_{2}$ results in changes in $\mathrm{PaO}_{2} / \mathrm{FiO}_{2} .{ }^{5,22}$ In addition, since it is likely that a significant proportion of patients included in those multicenter studies were on $\mathrm{FiO}_{2} \leq 0.4$ at the time of study enrollment, there is no information on how many patients could not meet ARDS criteria if they were evaluated at a minimum level of $\mathrm{FiO}_{2}=0.5$. Fifth, 518 patients were eliminated from the empirical analysis because PEEP was missing or was $<5 \mathrm{cmH}_{2} \mathrm{O}$. In our prospective studies, ${ }^{3,8}$ we did not exclude any patient based on the baseline PEEP or $\mathrm{FiO}_{2}$ at the time of ARDS diagnosis. Based on the wide range of $\mathrm{FiO}_{2}$ and PEEP levels at the time of AECC ARDS diagnosis, we found that a standard ventilator setting can improve oxygenation sufficiently to convert patients meeting the AECC ARDS definition on PEEP $<5 \mathrm{cmH}_{2} \mathrm{O}$ and/or on $\mathrm{FiO}_{2} \leq 0.4$ to
non-ARDS patients. Sixth, since there was no standardization of ventilator settings for measuring $\mathrm{PaO}_{2}$, and since more than $50 \%$ of patients were on PEEP $<10 \mathrm{cmH}_{2} \mathrm{O}$ at baseline, the experts' panel only selected a unique level of PEEP ( $\geq 5 \mathrm{cmH}_{2} \mathrm{O}$ ) as a requirement for the proposed empirical ARDS definition. We had found that when all patients are evaluated under the same standard ventilator settings, only the evaluation under a $P E E P \geq 10$ reached statistical significance for association of $\mathrm{PaO}_{2} / \mathrm{FiO}_{2}$ category with ICU mortality. ${ }^{5}$ Seventh, among other considerations (strict entry criteria for the trials), those studies do not include all consecutive ARDS patients admitted into the ICU since patients with pre-existent chronic diseases, patients over a certain age, and patients with established organ dysfunction were excluded. Eighth, the 4 multicenter studies were a case-mix of observational studies and clinical trials performed from 1996 to 2000, when patients were ventilated with tidal volumes $\geq 10 \mathrm{ml} / \mathrm{kg}$ predicted body weight (currently considered as an injurious tidal volume) and low levels of PEEP, and studies performed after the year 2000 (when patients were ventilated with lower tidal volumes). It has been postulated that the development of ARDS should have decreased because of advances in supportive care, particularly the application of protective mechanical ventilation. ${ }^{23}$ Ninth, there is a great discrepancy between the number of patients included in the database from the three-single centers and the number of patients reported in the original publications. We have re-examined those publications and have noted that they only studied 75 non-consecutive, selected ALI/ARDS instead of the 269 that are claimed by the experts' panel. Tenth, the experts' panel failed to evaluate their patients at $24 \mathrm{~h}$ after ARDS diagnosis. There is no information about the number of patients who did not meet ARDS criteria at $24 \mathrm{~h}$ of study entry under the same arbitrary condition $(P E E P \geq 5)$. Taking into consideration all the above, and based on our previous studies, we postulate that at least $50 \%$ of those patients would have $\mathrm{PaO}_{2} / \mathrm{FiO}_{2}>200 \mathrm{mmHg}$, and at least $25 \%$ would have a $\mathrm{PaO}_{2} / \mathrm{FiO}_{2}>300 \mathrm{mmHg}$ $24 \mathrm{~h}$ after ARDS identification on a PEEP $\geq 10$ and $\mathrm{FiO}_{2} \geq 0.5$.

In conclusion, we need more specific guidelines based on a standard method of evaluating oxygenation status (i.e. a specific level of PEEP and $\mathrm{FiO}_{2}$ ) in order to properly classify the severity of patients with and as ARDS. As we have reported in the several studies discussed in this review, a large variability in the severity of lung damage exists in patients meeting the AECC definition of ARDS and a strong correlation exists between oxygenation impairment at $24 \mathrm{~h}$ after ARDS onset and ICU outcome. The judicious use of PEEP, $\mathrm{FiO}_{2}$ and tidal volume in critically ill patients in the last decade has made ARDS a rare syndrome in today's modern ICUs. However, no matter how infrequently we observe its presence we need to be able to properly classify its severity. The AECC ARDS definition is dead, long live PEEP!

\section{Funding}

Supported by Instituto de Salud Carlos III, Spain (PI 10/0393) and the Asociación Científica Pulmón y Ventilación Mecánica. 


\section{Conflict of interest}

The authors have no conflict of interest to declare.

\section{References}

1. http://en.wikipedia.org/wiki/The_King_is_dead._Long_live_ the_King.

2. Bernard GR, Artigas A, Brigham KL, Carlet J, Falke K, Hudson L, et al. The American-European Consensus Conference on ARDS. Am J Respir Crit Care Med. 1994;149(3 Part 1): 818-24.

3. Villar J, Pérez-Méndez L, Kacmarek RM. Current definitions of acute lung injury and the acute respiratory distress syndrome do not reflect their true severity and outcome. Intensive Care Med. 1999;25:930-5.

4. Villar J, Kacmarek RM, Pérez-Méndez L, Aguirre-Jaime A. A high positive end-expiratory pressure, low tidal volume ventilatory strategy improves outcome in persistent acute respiratory distress syndrome: a randomized, controlled trial. Crit Care Med. 2006;34:1311-8.

5. Villar J, Pérez-Méndez L, López J, Belda J, Blanco J, Saralegui I, et al., HELP Network. An early $\mathrm{PEEP} / \mathrm{FIO}_{2}$ trial identifies different degrees of lung injury in patients with acute respiratory distress syndrome. Am J Respir Crit Care Med. 2007; 176:795-804.

6. The ARDS Definition Task Force. Acute respiratory distress syndrome. JAMA. 2012;307:2526-33.

7. Villar J, Blanco J, Añón JM, Santos-Bouza A, Blanch L, Ambrós A, et al. The ALIEN study: incidence and outcome of acute respiratory distress syndrome in the era of lung protective ventilation. Intensive Care Med. 2011;37:1932-41.

8. López-Fernández Y, Martínez-de Azagra A, de la Oliva P, Modesto V, Sánchez JI, Parrilla J, et al. The Pediatric Alien Study: incidence and outcome of the acute respiratory distress syndrome in children. Crit Care Med. 2012;40. (in press).

9. Ashbaugh DG, Bigelow DB, Petty TL, Levine BE. Acute respiratory distress in adults. Lancet. 1967;2:319-23.

10. Villar J. What is the acute respiratory distress syndrome? Respir Care. 2011;56:1539-45.

11. Ferguson ND, Kacmarek RM, Chiche JD, Singh JM, Hallett DC, Mehta S, et al. Screening of ARDS patients using standardized ventilator settings: influence on enrollment in a clinical trial. Intensive Care Med. 2004;30:1111-6.

12. Villar J, Pérez-Méndez L, Aguire-Jaime A, Kacmarek R. Why are physicians so skeptical about positive randomized controlled clinical trials in critical care medicine? Intensive Care Med 2005;31:196-204.

13. The Acute Respiratory Distress Syndrome Network. Ventilation with lower tidal volumes as compared with traditional tidal volumes for acute lung injury and the acute respiratory distress syndrome. The Acute Respiratory Distress Syndrome Network. N Engl J Med. 2000;342:1301-8.

14. Santos C, Ferrer M, Roca J, Torres A, Hernandez C, RodriguezRoisin 0 . Pulmonary gas exchange response to oxygen breathing in acute lung injury. Am J Respir Crit Care Med. 2000;161: 26-31.

15. Gattinoni L, Pesenti A, Bombino M, Baglioni S, Rivolta M, Rossi $G$, et al. Relationships between lung computed tomographic density, gas exchange, and PEEP in acute respiratory failure. Anesthesiology. 1988;69:824-32.

16. The National Heart Lung, Blood Institute, ARDS, Clinical Trials Network. Mechanical ventilation with higher versus lower positive end-expiratory pressures in patients with acute lung injury and the acute respiratory distress syndrome. $N$ Engl J Med. 2001;351:327-36.

17. Guerin C, Gaillard S, Lemasson S, Ayzac L, Girard R, Beuret $P$, et al. Effects of systematic prone positioning in hypoxemic acute respiratory failure: a randomized controlled trial. JAMA. 2004;292:2379-87.

18. Taylor RW, Zimmerman JL, Dellinger RP, Straube RC, Criner GJ, Davis Jr K, et al. Low dose inhaled nitric oxide in patients with acute lung injury: a randomized controlled trial. JAMA. 2004;291:1603-9.

19. Luhr OR, Antonsen K, Karlsson M, Aardal S, Thorsteinsson A, Frostell CG, et al., The ARF Study Group. Incidence and mortality after acute respiratory failure and acute respiratory distress syndrome in Sweden, Denmark and Iceland. Am J Respir Crit Care Med. 1999;159:1849-61.

20. Bersten AD, Edibam C, Hunt T, Moran J, The Australian, New Zeland Intensive Care Society Clinical Trials Group. Incidence and mortality of acute lung injury and the acute respiratory distress syndrome in three Australian states. Am J Respir Crit Care Med. 2002;165:443-8.

21. Rubenfeld GD, Caldwell E, Peabody E, Weaver J, Martin DP, Neff $M$, et al. Incidence and outcomes of acute lung injury. $N$ Engl J Med. 2005;353:1685-93.

22. Karbing DS, Kjaergaard S, Smith BW, Espersen K, Allerød C Andreassen $\mathrm{S}$, et al. Variation in the $\mathrm{PaO}_{2} / \mathrm{FiO}_{2}$ ratio with $\mathrm{FiO}_{2}$ : mathematical and experimental description, and clinical relevance. Crit Care. 2007;11:R118.

23. Villar J, Slutsky AS. Is acute respiratory distress syndrome an iatrogenic disease? Crit Care. 2010;14:120. 